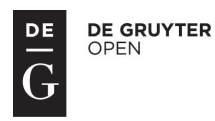

\title{
The Impact of Minimum Wage Changes on Management IN THE CZECH REPUBLIC
}

\author{
Natalie Uhrová ${ }^{1}$, Petr Skalka ${ }^{2}$
}

\begin{abstract}
The extent of social security contributions paid by both employers and employees in the Czech Republic is considered one of the biggest problems of the Czech economy. At the same time, the minimum wage in the Czech Republic has been repeatedly changed in recent years and even months, and thus the aim of this paper is to identify and discuss possible consequent changes in managerial decisions in Czech firms that could be examined in further analyses. We suggest the hypothesis that Czech firms are lowering their costs via the substitution of employment agreements for employment contracts in order to avoid social security contributions paid by the employer.
\end{abstract}

\section{Keywords}

Social Security Contribution, Minimum Wage, Employment Agreement

\section{Introduction}

The minimum wage is considered a form of social protection of employees as well as an economic motivation to enter the labour market and be employed instead of being dependent on social benefits. In the Czech Republic, the minimum wage was not changed for six years. But it has recently been changed several times, and thus some questions have arisen. Not only as to what effects this will have on the Czech economy, but also what effects it will have on managerial decisions in Czech firms.

There is a very well-known argument made by many economists that the minimum wage negatively affects unemployment, especially in the case of low-skilled workers. But the microeconomic point of view is no less important, although it is neglected in the literature. The minimum wage unavoidably impacts the costs of firms, and frequent changes in its level requires serious management decisions. Such decisions may also include some measures

\footnotetext{
${ }^{1}$ University of Economics in Ostrava, Mojmírovců 42, 70900 Ostrava, Czech Republic. E-mail: natalie.uhrova@vseo.cz.

${ }^{2}$ University of Economics in Ostrava, Mojmírovců 42, 70900 Ostrava, Czech Republic. E-mail: petr.skalka@vseo.cz.
} 
concerning types of contracts in order to minimize social security contributions paid by employers - the highest form of Czech taxation.

The aim of this paper is to identify and discuss possible changes in managerial decisions in Czech firms that could be examined in subsequent analyses using sophisticated statistical methods. In other words, the aim is to state the hypotheses for future research using a descriptive analysis of relevant data. The paper may also contribute to wider debate on this hot topic not only in the Czech Republic, but also in the entire European Union.

\section{Theoretical background}

Let us start with very simple and familiar reasoning. The theoretical background for the statement of hypotheses for future research is based on a simple microeconomic rule of maximization of profit (see, e.g. Samuelson and Nordhaus, 1995):

$$
M R=M C,
$$

where $M R$ is marginal revenue and $M C$ is marginal cost. It is necessary to remind the reader that we assume ideal competition on markets of goods and labour, and short run, i.e. labour is the only variable cost. Labour includes wage $(w)$ and social security contributions paid by the employer given by the rate ( $s s c r$ ). Then the profit is maximized if:

$$
M P L \cdot P=(1+s s c r) \cdot w,
$$

where $M P L$ is marginal product of labour and $P$ is price given by the market. Wage is then determined by the $M P L$ as:

$$
w=(M P L \cdot P) /(1+s s c r),
$$

where $P$ and $s s c r$ are constant. This is in fact in accordance with standard human capital theory (Becker, 1993) claiming that wage is a function of labour productivity. If the price and social security contribution rate are constant (given by the market or law), then the way to increase wage is to increase marginal product of labour.

\section{Possible reaction of a firm in the event of an increase in the minimum wage}

Under conditions of ideal competition, a firm has several options for how to deal with increases in the minimum wage in cases of increasing costs:

1. Adequate increase in the productivity of workers, which probably means higher investment in the human capital of workers (that may, however, be paid by employees);

2. Increase in productivity of workers, and decrease in number of workers (similar situation as 1.);

3. Substitution of capital for work, which is only possible in the long run;

4. Substitution of employment agreements for employment contracts to avoid social security contributions paid by the employer. 
The literature on this topic is very poor, but a study by Pernica (2015) presents the results of his own research among Czech firms. According to this study, $40 \%$ of Czech firms agree that the minimum wage increases unemployment, has an adverse effect on firm costs and reduces competitiveness.

The Czech tax mix is characterized by the relatively high social security contributions paid by both employees and employers. Nevertheless, the contributions on the employers' side are considered one of the most important factors negatively affecting the competitiveness of Czech firms (see, e.g. OECD, 2015). It is not surprising then that the method indicated in point (4) above is very often used for the reduction of labour costs. One could argue whether such behaviour on the part of firms is legal. But it was stated by the Czech Supreme Administrative Court that "rational economic behavior of entrepreneurs is also an effort to minimize costs and maximize profits. Natural manifestation of this behavior is the aim to optimize obligations to the state (e.g. tax, social security contribution). If this is done legally, i.e. in accordance with the Commercial Code and tax regulations, and also, e.g. The Employment Act, entrepreneurs cannot be penalized for it." (see the decisions of the Czech Supreme Administrative Court 2 Afs 173/ 2005 - 69 and 6 Afs 85 /2014).

In accordance with the text above, in the following chapter the data on the abovementioned measures is presented with the aim of finding some context between them.

\section{The minimum wage in the context of economic measures in the Czech Republic}

In figure (1), naturally, the initial development of the minimum wage is shown. The sixyear stagnation is evident in the period 2007-2013, as are the frequent changes in recent months and years.

Figure 1: Development of the minimum wage in the Czech Republic, 1993-2015

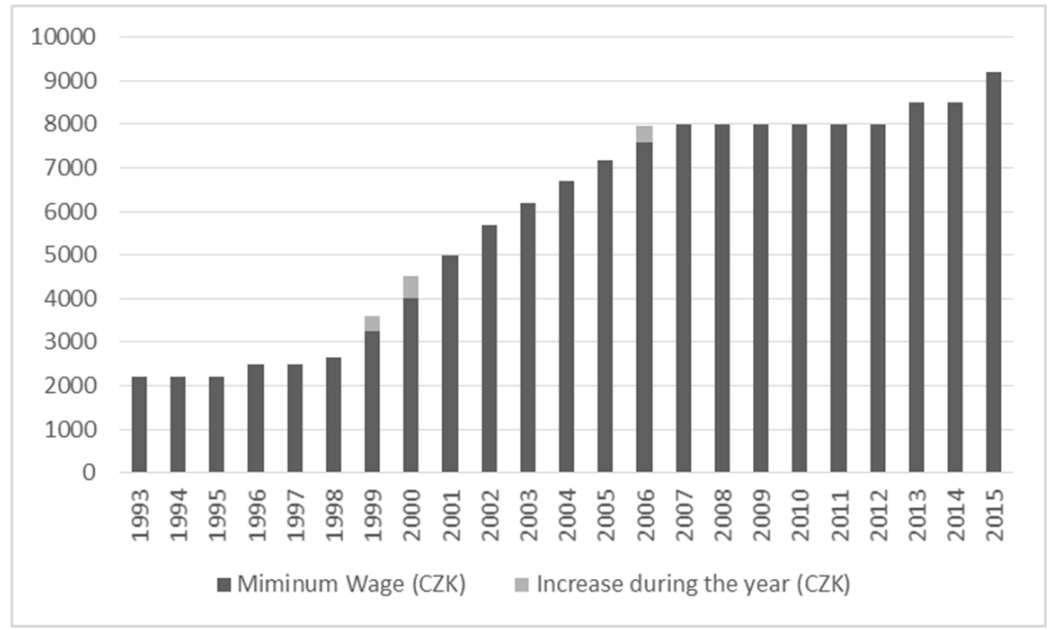

Source: Czech Statistical Office, 2015 
For any kind of analysis, however, it is necessary to express the minimum wage as a ratio, thereby eliminating the inflation rate and other influences, e.g. as a minimum wage to average wage ratio, as presented in figure (2). Such a measure is more likely to capture the effects of minimum wage development on human resources or financial management. If the ratio increases, it means that the increase in the minimum wage is not caused by an increase in wages in general, but by some other, rather non-economic factors.

Figure 2: Development of the minimum wage to average wage ratio in the Czech Republic, 1993-2015

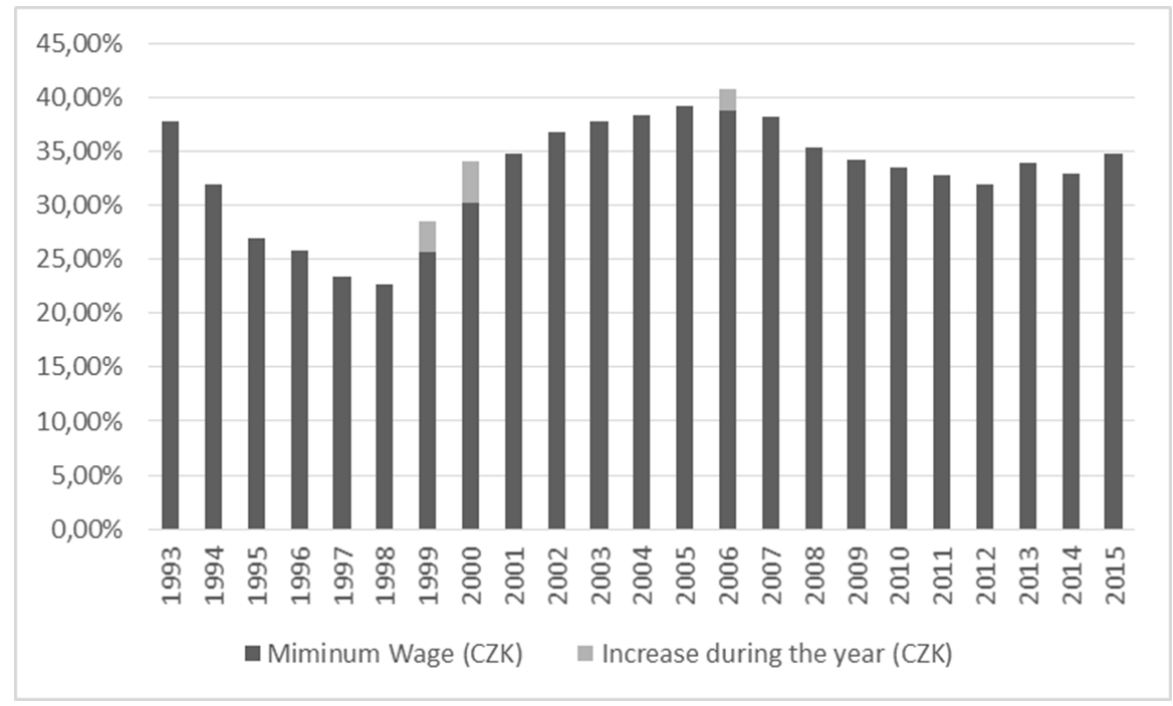

Source: Czech Statistical Office, 2015

Concerning the social security contributions, no change has been noticed. The rate of the social insurance rate was $27 \%$ in $1993,26.5 \%$ in $1994-1995,26 \%$ in $1996-2008$, and since 2009 it has been $25 \%$. The health insurance rate has been $9 \%$ since 1993 .

Figure (3) shows related data on the unemployment rate, labour productivity and investment in human capital (expenditure on education) made by the private sector, and their development in the Czech Republic in 1994-2015. The data was not available for 1993, and in the case of investment in human capital the data was available only for 2000-2011. As is apparent from the figures, the development of the minimum to average wage ratio is accompanied by rather similar development of other examined variables, although in their case the fluctuations are stronger and more likely to copy the business cycle. This is in accordance with economic theory and the abovementioned assumptions, although the situation may have been distorted by the economic crisis and the influences of many other factors. 
Figure 3: Development of unemployment, labour productivity and investment in human capital in the Czech Republic, 1994-2015

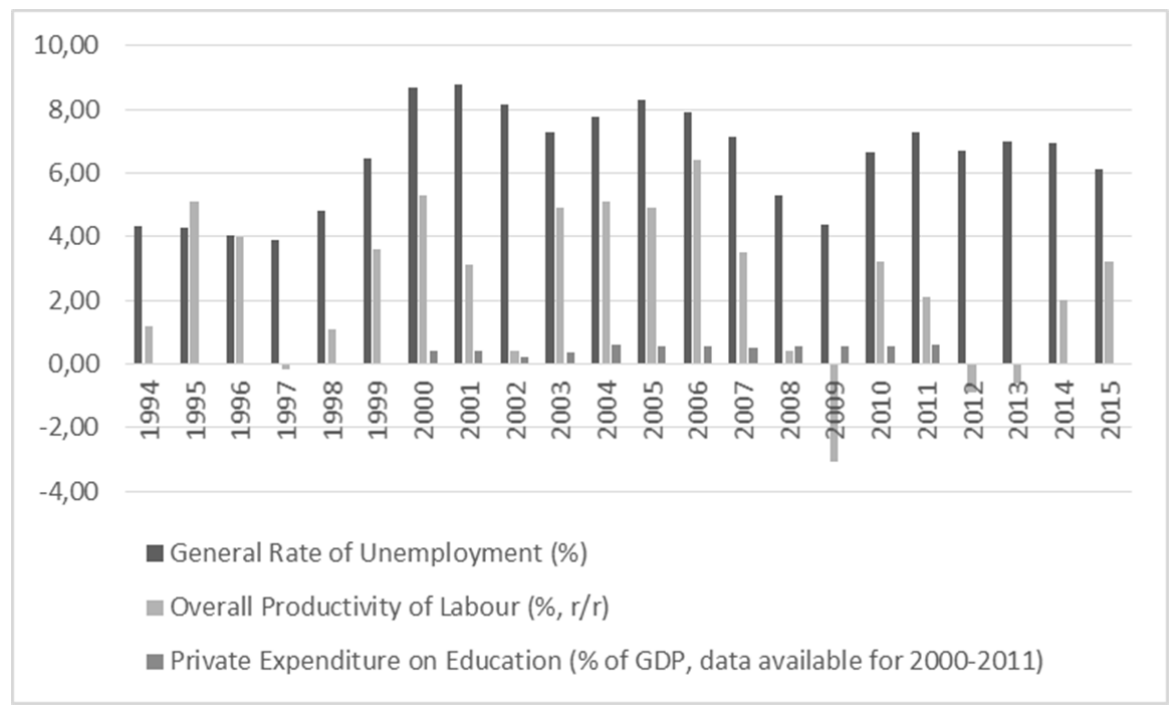

Source: Czech Statistical Office, Eurostat, 2015

As has already been stated, the increase in the minimum wage was massive, especially in the period 2000-2006 and then in 2013-2015. These increases should have been compensated for either by higher unemployment - although probably just in certain segments, higher productivity of labour, or by lower social security contributions to total labour costs ratio. In 2000-2006, the unemployment rate was relatively high, as well as there being increases in productivity of labour. However, there was a great decline in productivity growth in 2002. As is apparent from figure (4), this decline may have been compensated for by the lower ratio of social security contributions to total labour costs. The same appears in 2009, and in 2012-2013 - although on a much smaller scale. 
Figure 4: Development of social security contributions to total labour costs ratio $(\%)$ in the Czech Republic, 1993-2014

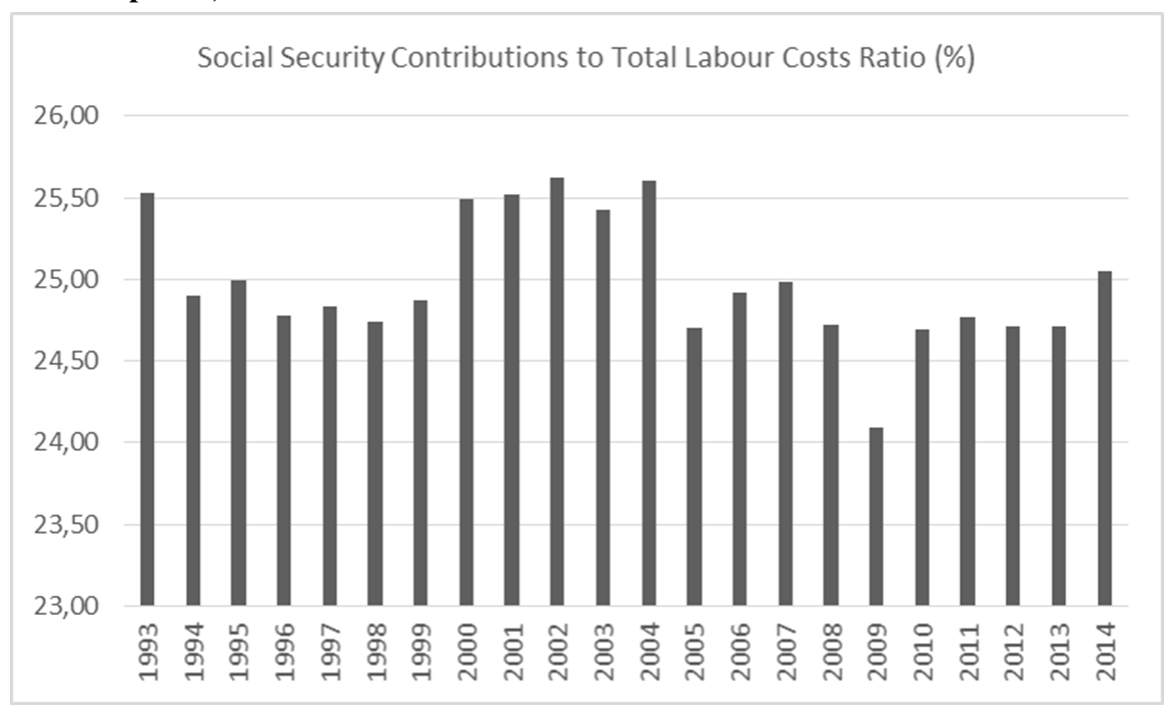

Source: Czech Statistical Office, 2015

This supports the hypothesis that if the increase in the minimum wage is not accompanied by an increase in labour productivity, Czech firms tend to lower labour costs by substituting employment agreements for employment contracts. This hypothesis will be further examined in future research using sophisticated statistical methods.

\section{Conclusion}

The aim of this paper was to identify and discuss possible changes in managerial decisions in Czech firms in connection with increases of the minimum wage. We claim that a firm has several options when it comes to dealing with increases in the minimum wage and the resulting increase in costs: (1) adequate increase in the productivity of workers, which probably means higher investment in human capital of workers (that may, however, be paid by employees); (2) increase in productivity of workers, and decrease in number of workers; (3) substitution of capital for work, which is possible only in the long run; and (4) substitution of employment agreements for employment contracts to avoid social security contributions paid by the employer. Based on a descriptive analysis of the Czech data, we suggest the hypothesis for future research that, if the increase in minimum wage is not accompanied by an increase in labour productivity, Czech firms tend to lower labour costs by substituting employment agreements for employment contracts. 


\section{References}

Becker, G. S. (1993). Human Capital: A Theoretical and Empirical Analysis with Special Reference to Education. University of Chicago Press.

Decision of the Czech Supreme Administrative Court No. 2 Afs 173/ 2005 - 69.

Decision of the Czech Supreme Administrative Court No. 6 Afs 85 /2014.

OECD. (2015). Taxing Wages 2015. OECD Publishing, Paris.

Pernica, M. (2015). The Effect of Current Minimum Wage Changes in the Czech Republic on the Enterprises. In Soliman, K. S. (ed.). Innovation Vision 2020. From Regional Development Sustainability to Global Economic Growth, Vol. I-IV, pp. 2335-2347.

Samuelson A. P., Nordhaus D. W. (1995). Economics. McGraw-Hill. 